\title{
PENGARUH INDEKS HARGA SAHAM SYARIAH INTERNASIONAL DAN VARIABEL MAKRO EKONOMI TERHADAP JAKARTA ISLAMIC INDEX
}

\author{
Irfan Syauqi Beik \& Sri Wulan Fatmawati ${ }^{1}$
}

\begin{abstract}
The Impact of International Islamic Stock Market and Macroeconomic Variables Towards Jakarta Islamic Index (JII). This research atempts to examine the impact of international Islamic stock market and macroeconomic variables towards Jakarta Islamic Index (JII). By using Vector Error Correction Model (VECM) as the method, this research utilizes time series monthly data from January 2007 to October 2012. The finding shows that JII is positively significantly affected by DJIEU, DJIMY and IPI, and it is negatively significantly affected by DJIJP, IMUS, M2 and SBIS.JII reaches its stability condition fastest when dealing with money supply shock. This study recommends: strengthening coordination between monetary authority and financial services authority, strengthening real sector of the economy, minimizing the influence of interest Rate towards Islamic financial market, and developing early warning system to anticipate financial crises.
\end{abstract}

Keywords: Macroeconomic Variables, VECM, Islamic Stock, JII

\begin{abstract}
Abstrak: Pengarub Indeks Harga Saham Syariah Internasional dan Variabel makroekonomi Terhadap Jakarta Islamic Indeks. Penelitian ini bertujuan untuk menguji pengaruh indeks harga saham syariah internasional dan variabel makroekonomi terhadap Jakarta Islamic Index (JII). Penelitian ini menggunakan metode Vector Error Correction Model (VECM), dengan data runtut waktu bulanan dari Januari 2007 sampai dengan Oktober 2012. Hasil studi menunjukkan bahwa JII dipengaruhi secara positif dan signifikan oleh DJIEU, DJIMY dan IPI, serta dipengaruhi secara negatif dan signifikan oleh DJIJP, IMUS, M2 dan SBIS. JII paling cepat mencapai kestabilan ketika merespon guncangan terhadap jumlah uang yang beredar (M2). Penelitian ini merekomendasikan penguatan koordinasi otoritas moneter dengan otoritas jasa keuangan, penguatan sektor riil, penguatan upaya meminimalisir pengaruh bunga terhadap pasar keuangan syariah, dan perlu dibangunnya sistem peringatan dini untuk mengantisipasi krisis keuangan.
\end{abstract}

Kata kunci: Variabel Makroekonomi, VECM, Saham Syariah, JII

${ }^{1}$ Diterima: 25 Pebruari 2014, direvisi: 25 Maret 2014, Disetujui: 16 April 2014

Fakultas Ekonomi dan Manajemen IPB, Jl. Raya Darmaga Kampus IPB Darmaga, Bogor, Email: irfan_beik@ipb.ac.id;

Pusat Studi Bisnis dan Ekonomi Syariah (CIBEST) IPB, Jl. Raya Darmaga Kampus IPB Darmaga, Bogor. Email: fatmawati.sriwulan@yahoo.co.id 


\section{PENDAHULUAN}

Pasar modal memiliki peranan yang sangat penting dalam perekonomian global saat ini. Sebagai negara yang pasar keuangannya tengah berkembang, pasar modal telah menjadi bagian penting dalam perekonomian Indonesia, baik sebagai tempat untuk menghimpun dana, tempat alternatif investasi melalui penjualan saham dan penerbitan obligasi, maupun sebagai indikator stabilitas kondisi makroekonomi.

Investasi di Indonesia saat ini sedang mengalami perkembangan yang cukup baik. Hal ini ditandai dengan semakin baiknya kinerja Indeks Harga Saham Gabungan (IHSG), LQ45, Jakarta Islamic Index (JII), dan Indeks Saham Syariah Indonesia (ISSI), yang merepresentasikan kondisi aktual pasar modal syariah nasional. Perkembangan pasar modal ini diharapkan mampu mendongkrak kinerja perekonomian nasional, sekaligus mengokohkan fundamental perekonomian dalam menghadapi kondisi dunia yang masih belum pulih benar akibat krisis keuangan global yang terjadi pada tahun 2008 lalu.

Munculnya produk syariah di pasar modal pada mulanya berawal dari keinginan untuk mengakomodasi kebutuhan umat Islam yang ingin melakukan investasi dengan prinsip syariah. Hal inilah yang kemudian melatarbelakangi PT Danareksa Investment Management untuk meluncurkan Danareksa Syariah pada tanggal 3 Juli 1997. Kemudian pada tanggal 3 Juli 2000, Bursa Efek Indonesia bekerjasama dengan PT Danareksa Investment Management meluncurkan Jakarta Islamic Index (JII). Selanjutnya, produk investasi syariah di pasar modal terus berkembang dengan kehadiran instrumen obligasi syariah (sukuk), reksadana syariah, dan Daftar Efek Syariah (DES) yang kemudian bertransformasi menjadi Indeks Saham Syariah Indonesia (ISSI). Bahkan jumlah saham syariah yang terdaftar di bursa terus mengalami peningkatan yang signifikan, yaitu hampir dua kali lipat dalam kurun waktu lima tahun, mulai 2007 hingga 2012, sebagaimana ditunjukkan oleh Tabel 1.

Tabel 1. Perkembangan Jumlah Saham Syariah

\begin{tabular}{ccc}
\hline Tahun & Periode & Jumlah Saham Syariah \\
\hline 2007 & I & 174 \\
& II & 183 \\
2008 & I & 191 \\
& II & 195 \\
2009 & I & 198
\end{tabular}




\begin{tabular}{|c|c|c|}
\hline & II & 199 \\
\hline \multirow[t]{2}{*}{2010} & I & 210 \\
\hline & II & 228 \\
\hline \multirow[t]{2}{*}{2011} & I & 234 \\
\hline & II & 253 \\
\hline \multirow[t]{2}{*}{2012} & I & 304 \\
\hline & II & 321 \\
\hline
\end{tabular}

Sumber: Bapepam LK (sekarang Otoritas Jasa Keuangan)

Tabel 1 juga mengindikasikan bahwa keberadaan saham syariah sangat diminati oleh para investor. Sedangkan nilai kapitalisasi saham syariah yang ditunjukkan oleh Jakarta Islamic Index mengalami fluktuasi pada periode yang sama, dimana pada tahun 2008 sempat mengalami penurunan sebagai dampak dari subprime crisis di Amerika Serikat. Namun, sebagaimana ditunjukkan oleh Tabel 2, nilai kapitalisasi saham syariah ini kembali menunjukkan tren kenaikan secara positif mulai tahun 2009 hingga 2012. Ini menunjukkan bahwa kinerja Jakarta Islamic Index mengalami peningkatan yang cukup baik.

Tabel 2 Tabel Kapitalisasi Saham Syariah

\begin{tabular}{cc}
\hline Tahun & $\begin{array}{c}\text { Jakarta Islamic Index } \\
\text { (Rp Miliar) }\end{array}$ \\
\hline 2007 & $1.105 .897,25$ \\
2008 & $428.525,74$ \\
2009 & $937.919,08$ \\
2010 & $1.134 .632,00$ \\
2011 & $1.414 .983,81$ \\
2012 & $1.671 .004,23$ \\
\hline
\end{tabular}

Sumber: Bapepam LK (sekarang Otoritas Jasa Keuangan)

Jika dilihat dari perspektif sejarah, negara yang pertama kali mengembangkan indeks syariah dan equity fund seperti reksadana adalah Amerika Serikat. Hal ini ditandai dengan peluncuran The North American Islamic Trust sebagai equity fund pertama di dunia pada tahun 1986 oleh The Amana Fund. Selanjutnya pada bulan Februari 1999, Dow Jones meluncurkan indeks pasar syariah yang pertama, yaituDow Jones Islamic Market Index (DJIMI) merupakan bagian dari kelompok indeks-indeks global Dow Jones (Dow Jones Global Index atau DJGI). Hal ini membuktikan 
bahwa Amerika Serikat adalah negara yang pertama kali melaksanakan kegiatan pasar modal syariahdi dunia (Huda dan Nasution, 2008). Ini juga membuktikan bahwa konsep ekonomi syariah adalah konsep yang berlaku universal dan diterima oleh berbagai kalangan.

Dow Jones Islamic Market Index ini meliputi saham-saham dari 34 negara, serta mencakup 10 sektor ekonomi, 18 sektor pasar, 51 kelompok industri dan 89 subkelompok industri. Beberapa negara yang termasuk ke dalam Dow Jones Islamic Market Index diantaranya adalah Dow Jones Islamic Market Index Europe (DJIEU), Dow Jones Islamic Market Index Malaysia (DJIMY), Dow Jones Islamic Market Index US (IMUS),dan Dow Jones Islamic Market Index Japan (DJIJP). Saham-saham syariah yang ada di negara-negara tersebut merupakan saham dengan harga yang cukup tinggi dibandingkan dengan negara-negara lainnya. Gambar 1 menunjukkan bagaimana pergerakan harga saham syariah yang ada di negara-negara tersebut jika dibandingkan dengan Jakarta Islamic Index.

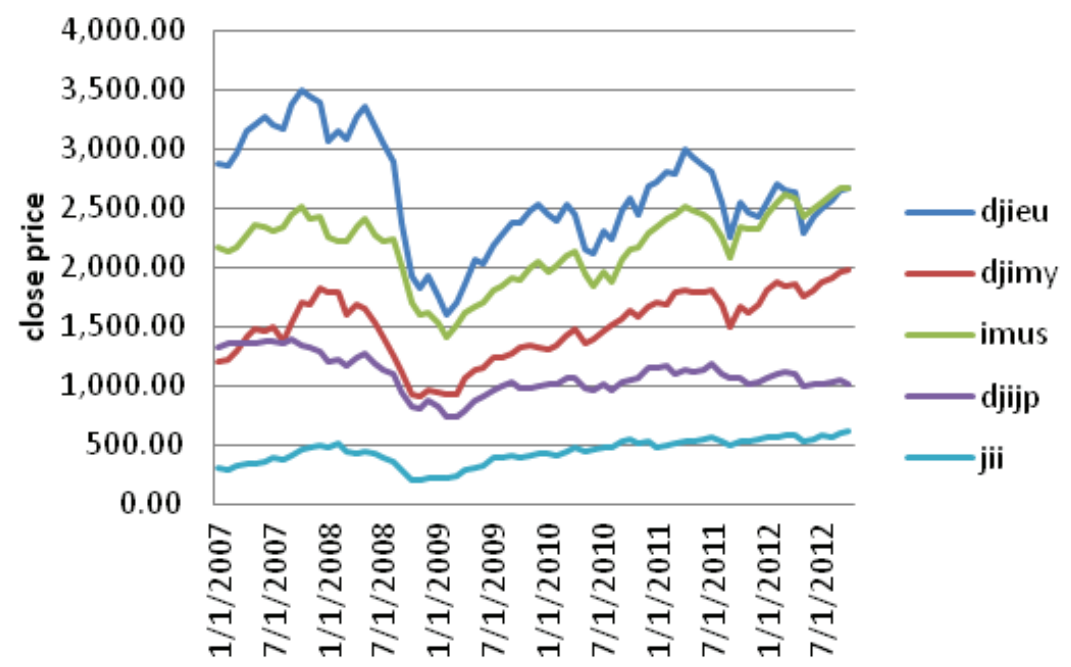

Gambar 1. Indeks Harga Saham Beberapa Negara

Sumber: www.finance.yahoo.com

Dari gambar tersebut dapat dilihat bahwaharga saham syariah yang paling tinggi dimiliki oleh Dow Jones Islamic Market Index Europe, diikuti oleh Dow Jones Islamic Market Index US, Dow Jones Islamic Market Index Malaysia, Dow Jones Islamic Market Index Japan dan Jakarta Islamic Index. Gambar tersebut juga menunjukkan bahwapada bulan September dan Oktober 2008 saham-saham syariah tersebut mengalami penurunan akibat krisis keuangan global.Meski demikian, menurut Beik dan Wardhana (2011) kinerja Jakarta Islamic Index, yang beranggotakan 30 
saham yang paling likuid dan memiliki nilai kapitalisasi yang sangat besar, terbukti secara empiris lebih stabil dibandingkan dengan kinerja pasar-pasar saham lainnya.

Dari data dan fakta di atas, dapat dilihat bahwa kinerja pasar saham syariah sangat dipengaruhioleh gejolak yang terjadi di pasar saham internasional. Hal ini terjadi sebagai akibat semakin terintegrasikannya pasar-pasar saham yang ada di dunia, sehingga gejolak yang terjadi di suatu negara, dapat memengaruhi kondisi negara lain secara signifikan. Demikian pula dengan stabilitas kondisi makroekonomi. Meski pasar saham syariah Indonesia sempat terpukul akibat krisis 2008, namun karena kondisi makroekonomi nasional yang relatif stabil dan masih menunjukkan pertumbuhan yang positif, maka Jakarta Islamic Index pun mampu menunjukkan kinerja recovery yang lebih baik. Untuk itu, penelitian ini bertujuan untuk menganalisis pengaruh indeks harga saham syariah di beberapa negara dan variabel makroekonomi nasional terhadap kinerja Jakarta Islamic Index. Adapun pasar saham syariah negara lain yang diteliti pengaruhnya dalam studi ini adalah Amerika Serikat, Uni Eropa, Jepang dan Malaysia.

\section{TINJAUAN PUSTAKA}

Ada beberapa studi yang berusaha menguji pengaruh indeks harga saham dan variabel makroekonomi baik secara regional maupun global. Ibrahim dan Yusoff (2001), Maghayereh (2003), Maysami et al. (2004), Menike (2006), Nugraha (2007), Yusof dan Majid (2007), Yusof dan Majid (2009), Asmy et al. (2010), Savasa dan Samiloglub (2010), Syukma (2011), Albaity (2011), Beik dan Wardhana (2011), Rad (2011), Kuwomu dan Victor (2011), Hosseini et al. (2011), Istiqomah (2012), Hussin et al. (2012), Bekhet dan Mugableh (2012), serta Majid et al. (2012) adalah beberapa studi yang menguji pengaruh indeks harga saham dan variabel makroekonomi.

Pada studi-studi tersebut, variabel makroekonomi yang digunakan adalah Industrial Production Index (IPI) yang terbukti memiliki hubungan yang positif dengan harga saham (Maysami et al. 2004). Hal ini juga sesuai dengan penelitian Ibrahim dan Yusoff (2001), Maghayereh (2003), Nugraha (2007), Savasa dan Samiloglub (2010), Syukma (2011), Hosseini et al. (2011), Hussin et al. (2012), Bekhet dan Mugableh (2012), dan Majid et al. (2012). Peningkatan IPI akan memengaruhi harga saham melalui dampaknya terhadap keuntungan perusahaan. Hubungan antara Indeks Harga Konsumen atau Consumer Price Index (CPI) dan harga saham dapat berpengaruh positif maupun negatif. Menurut Maghayereh (2003), Syukma (2011), dan Bekhet dan Mugableh (2012) kedua variabel tersebut memiliki hubungan yang negatif. Mereka menyatakan bahwa naiknya CPI 
mengindikasikan naiknya harga-harga barang konsumsi, yang berarti meningkatnya biaya hidup masyarakat. Hal ini membuat masyarakat memilih mengalokasikan dananya untuk konsumsi daripada investasi. Akibatnya, permintaan saham pada pasar modal akan mengalami penurunan. Rendahnya permintaan membuat harga saham akan turun. Namun demikian, beberapa penelitian lain menunjukkan bahwa kedua variabel tersebut memiliki hubungan yang positif. Ibrahim dan Yusoff (2001), Maysami et al. (2004), Menike (2006), Asmy et al. (2010), Kuwomu dan Victor (2011), Hosseini et al. (2011), Hussin et al. (2012) menemukan bahwa CPI berhubungan positif dengan harga saham.

Selanjutnya, hubungan antara jumlah uang beredar dengan harga saham dapat berpengaruh positif maupun negatif. Maysami et al. (2004), Menike (2006), Yusof dan Majid (2009), Hosseini et al. (2011), Majid et al. (2012) menunjukkan bahwa ketika terjadi kenaikan jumlah uang beredar, suku bunga akan mengalami penurunan. Dalam konteks ini investor akan menginvestasikan dananya pada pasar modal. Peningkatan investasi yang terjadi di pasar modal akan memengaruhi permintaan saham. Semakin banyak permintaan maka harga sahampun akan mengalami peningkatan. Namun Ibrahim dan Yusoff (2001), Asmy et al. (2010), Hussin et al. (2012), Bekhet dan Mugableh (2012) menunjukkan fakta sebaliknya, dimana hubungan kedua variabel tersebut ternyata bersifat negatif.

Adapun nilai tukar dan harga saham dapat pula berpengaruh positif maupun negatif.Studi yang dilakukan Maysami et al. (2004), Nugraha (2007), Asmy et al. (2010) menunjukkan hubungan positif antara kedua variabel. Namun menurut Ibrahim dan Yusoff (2001), Menike (2006), Yusof dan Majid (2009), Syukma (2011), Kuwomu dan Victor (2011), Hussin et al. (2012), Bekhet dan Mugableh (2012), dan Majid et al. (2012), hubungan kedua variabel tersebut negatif. Hal ini mengindikasikan bahwa ketika nilai tukar rupiah mengalami depresiasi maka investor akan mengalihkan dananya ke luar negeri sehingga terjadi capital outflow. Mengalirnya dana ke luar negeri menyebabkan investasi dalam negeri mengalami penurunan. Penurunan ini berdampak pada berkurangnya investasi pada saham di pasar domestik sehingga harga saham pun ikut mengalami penurunan.

Menurut penelitian Maghayereh (2003), Menike (2006), Kuwomu dan Victor (2011), Hussin et al. (2012) suku bunga berpengaruh negatif terhadap harga saham. Hal ini dikarenakan oleh perilaku investor yang cenderung menanamkan dananya dalam bentuk investasi selain saham, sehingga harga saham menjadi turun.

Studi yang dilakukan Yusof dan Majid (2007) menunjukkan bahwa volatilitas tingkat suku bunga memengaruhi volatilitas pasar saham konvensional tetapi tidak memengaruhi pasar saham syariah. Hal ini sejalan dengan prinsip syariah bahwa 
suku bunga bukan merupakan variabel yang signifikan dalam menjelaskan volatilitas pasar saham. Temuan ini memberikan dukungan lebih lanjut bahwa suku bunga berdampak tidak signifikan terhadap volatilitas pasar saham syariah.

Dalam konteks pasar modal antar negara, studi Beik dan Wardhana (2011), dengan menggunakan data bulan Januari 2006 sampai dengan Desember 2008, menunjukkan bahwa tidak ada hubungan jangka panjang antara pasar modal Indonesia dengan Malaysia dan Amerika Serikat. Kemudian Jakarta Islamic Index adalah yang paling stabil dibandingkan dengan indeks saham di Malaysia dan Amerika Serikat. Hal ini dapat dijadikan sebagai alternatif investasi bagi para investor. Bagi Indonesia sendiri, kondisi ini seharusnya dimanfaatkan untuk mempromosikan pasar modal dalam negeri sebagai tujuan investasi yang menguntungkan.

Sementara riset yang dilakukan Rad (2011) menunjukkan bahwa respon indeks harga saham di Iran terhadap guncangan dalam variabel ekonomi makro seperti indeks harga konsumen, nilai tukar dan jumlah uang yang beredar, sangat lemah dan membutuhkan waktu empat bulan untuk stabil. Kemudian studi tersebut juga menunjukkan bahwa variabel makroekonomi seperti indeks harga konsumen, nilai tukar mata uang dan jumlah uang yang beredar berfluktuasi sekitar 12persen.

\section{METODE}

Analisis pengaruh indeks harga saham syariah di Amerika Serikat, Uni Eropa, Jepang dan Malaysia, dan variabel makroekonomi nasional terhadap Jakarta Islamic Index (JII) dilihat dengan menggunakan sejumlah variabel, yaitu Jakarta Islamic Index (JII), Industrial Production Index (IPI), Consumer Price Index (CPI), jumlah uang beredar (M2), nilai tukar atau exchange Rate (ER), suku bunga Bank Indonesia (BI Rate), Sertifikat Bank Indonesia Syariah (SBIS), Dow Jones Islamic Market Index Europe (DJIEU), Dow Jones Islamic Market Index Malaysia (DJIMY), Dow Jones Islamic Market Index US (IMUS), dan Dow Jones Islamic Market Index Japan (DJIJP). Adapun model penelitian ini adalah:

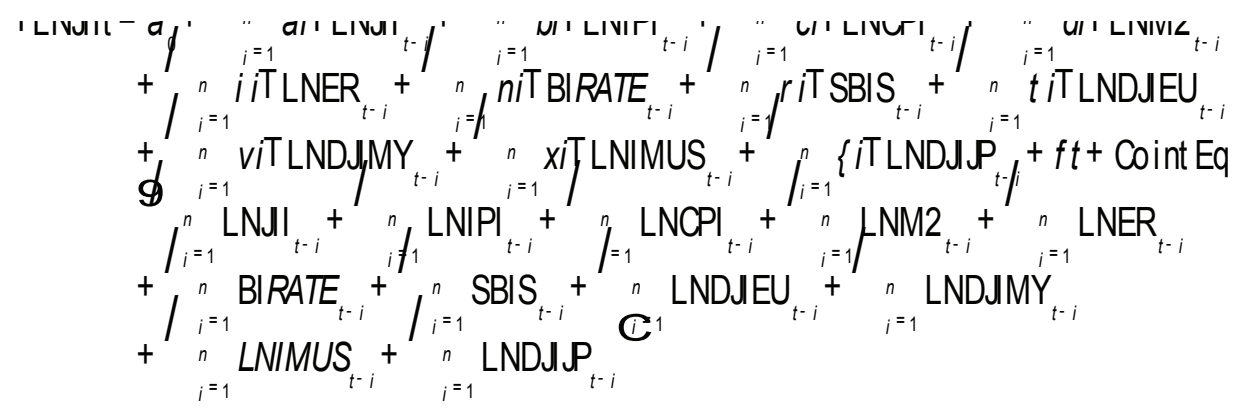


dimana:

LNJII = Jakarta Islamic Index

$\begin{array}{ll}\text { LNIPI } & =\text { Industrial Production Index (IPI) dengan tahun dasar } 2010 \\ \text { LNCPI } & =\text { Consumer Price Index (CPI) dengan tahun dasar } 2007 \\ \text { LNM2 } & =\text { Jumlah uang yang beredar dalam arti luas } \\ \text { LNER } & =\text { Nilai tukar rupiah terhadap dolar AS (Rp/USD) } \\ \text { BIRATE } & =\text { suku bunga Bank Indonesia } \\ \text { SBIS } & =\text { Sertifikat Bank Indonesia Syariah (SBIS) satu bulan } \\ \text { LNDJIEU } & =\text { Dow Jones Islamic Market Index Eropa } \\ \text { LNDJIMY } & =\text { Dow Jones Islamic Market Index Malaysia } \\ \text { LNIMUS } & =\text { Dow Jones Islamic Market Index Amerika Serikat } \\ \text { LNDJIJP } & =\text { Dow Jones Islamic Market Index Jepang } \\ \alpha_{0} & =\text { Intersep } \\ \in & =\text { Error term }\end{array}$

Berikut ini penjelasan mengenai variabel-variabel yang digunakan dalam penelitian :

a. Jakarta Islamic Index (JII) adalah indeks saham berbasis syariah yang ada di Indonesia.

b. Industrial Production Index (IPI) adalah sebuah indikator ekonomi yang mengukur produksi output riil. IPI sering digunakan sebagai representasi bagi pendapatan nasional untuk menggantikan ketiadaan data PDB bulanan. IPI yang digunakan dalam penelitian ini menggunakan tahun dasar 2010.

c. Consumer Price Index (CPI) adalah gambaran tingkat harga barang dan jasa yang dikonsumsi masyarakat. CPI ini dinyatakan dalam bentuk indeks dan berupa data bulanan. CPI juga merupakan gambaran tingkat inflasi, dan penelitian ini menggunakan CPI tahun dasar 2007.

d. Jumlah uang beredar (M2) merupakan jumlah uang beredar dalam arti luas.

e. Exchange Rate (ER) merupakan nilai tukar rupiah terhadap dolar AS (Rp/ USD).

f. BI Rate menggambarkan tingkat suku bunga Bank Indonesia.

g. SBIS adalah bonus Sertifikat Bank Indonesia Syariah (SBIS).Penelitian ini menggunakan data SBIS satu bulan.

h. Dow Jones Islamic Market Index Europe (DJIEU) adalah indeks harga saham berbasis syariah yang ada di Eropa.

i. Dow Jones Islamic Market Index Malaysia (DJIMY) adalah indeks harga saham berbasis syariah yang ada di Malaysia.

j. Dow Jones Islamic Market Index US (IMUS) adalah indeks harga saham berbasis 
syariah yang ada di Amerika Serikat.

k. Dow Jones Islamic Market Index Japan (DJIJP) adalah indeks harga saham berbasis syariah yang ada di Jepang.

Jenis data yang digunakan dalam penelitian ini merupakan data sekunder berupa time series bulanan dari Januari 2007 sampai dengan Oktober 2012. Data-data untuk penelitian ini diperoleh dari berbagai sumber diantaranya: Badan Pengawas Pasar Modal Lembaga Keuangan (BAPEPAM LK), Bursa Efek Indonesia (BEI), Badan Pusat Statistik (BPS), Bank Indonesia (BI), dan yahoofinance. Adapun data yang digunakan adalah data indeks harga Jakarta Islamic Index (JII), data Industrial Production Index (IPI), data Consumer Price Index (CPI), data jumlah uang beredar (M2), data Exchange Rate (ER), data BI Rate, data Sertifikat Bank Indonesia Syariah (SBIS), data Dow Jones Islamic Market Index Europe (DJIEU), data Dow Jones Islamic Market Index Malaysia (DJIMY), data Dow Jones Islamic Market Index US (IMUS), dan data Dow Jones Islamic Market Index Japan (DJIJP).

Penelitian ini menggunakan metode analisis yang bersifat deskriptif dan kuantitatif. Alat analisis yang digunakan dalam penelitian ini adalah metode Vector Autoregression (VAR) apabila data yang digunakan stasioner pada level. Namun bila data belum stasioner pada tingkat level maka dilanjutkan dengan metode Vector Error Correction Model (VECM). Semua data dalam penelitian ini ditransformasikan ke dalam bentuk logaritma natural (ln) kecuali BI Rate dan SBIS.

Model Vector Autoregressive (VAR) diperkenalkan oleh Christopher Sims pada tahun 1980. Firdaus (2011) memaparkan bahwa jika sebelumnya univariate autoregression merupakan sebuah persamaan tunggal (single equation) dengan model linier variabel tunggal (single-variable linear model), di mana nilai sekarang dari masing-masing variabel dijelaskan oleh nilai lag-nya sendiri, maka VAR merupakan sebuah $\mathrm{n}$-persamaan dengan $\mathrm{n}$-variabel, di mana masing-masing variabel dijelaskan oleh nilai lag-nya sendiri, serta nilai saat ini dan masa lampaunya (current and past values).

Menurut Firdaus (2011), alat analisis yang disediakan oleh VAR bagi deskripsi data, peramalan, inferensi struktural, dan analisis kebijakan dilakukan melalui empat macam penggunaannya, yakni Forecasting, Impuls Response Function(IRF), Forecast Error Variance Decomposition (FEVD), dan Granger Causality Test.Adapun persamaan umum VAR adalah sebagai berikut (Firdaus 2011):

$\mathrm{y}_{\mathrm{t}}=\mathrm{A}_{0}+\mathrm{A}_{1} \mathrm{y}_{\mathrm{t}-1}+\mathrm{A}_{2} \mathrm{y}_{\mathrm{t}-2}+\ldots+\mathrm{A}_{\mathrm{p}} \mathrm{y}_{\mathrm{t}-\mathrm{p}}+\epsilon_{\mathrm{t}}$

dimana:

$\mathrm{y}_{\mathrm{t}} \quad=$ vektor berukuran $(n .1)$ yang berisikan $\mathrm{n}$ variabel yang terdapat dalam sebuah model VAR 
$\mathrm{A}_{0} \quad=$ vektor intersep berukuran $(n .1)$

$\mathrm{A}_{\mathrm{i}} \quad=$ matriks koefisien/ parameter berukuran (n.n) untuk setiap $i=1,2, \ldots, \mathrm{p}$

$\epsilon_{\mathrm{t}} \quad=$ vektor error berukuran $(n .1)$

Vector Error Correction Model (VECM) merupakan bentuk VAR yang terestriksi (Firdaus, 2011). Restriksi tambahan ini harus diberikan karena keberadaan bentuk data yang tidak stasioner pada level, VECM kemudian memanfaatkan informasi restriksi kointegrasi tersebut ke dalam spesifikasinya. Oleh karena itu VECM sering disebut sebagai desain VAR bagi series nonstasioner yang memiliki hubungan kointegrasi. Dengan demikian, dalam VECM terdapat speed of adjustment dari jangka pendek ke jangka panjang (Firdaus 2011).

Adapun model VECM secara umum adalah sebagai berikut:

$\Delta \mathrm{y}_{\mathrm{t}}=\mu_{0 \mathrm{x}}+\mu_{1 \mathrm{x}} \mathrm{t}+\Pi_{\mathrm{x}} \mathrm{y}_{\mathrm{t}-1}+\Delta \mathrm{y}_{\mathrm{t}-\mathrm{i}}+\varepsilon_{\mathrm{t}}$

dimana:

$\mathrm{y}_{\mathrm{t}} \quad=$ vektor yang berisi variabel yang dianalisis dalam penelitian

$\mu_{0 \mathrm{x}} \quad=$ vektor intersep

$\mu_{1 \mathrm{x}} \quad=$ vektor koefisien regresi

$t \quad=$ time trend

$\Pi_{\mathrm{x}} \quad=\alpha_{\mathrm{x}} \beta^{\prime}$ dimana $b^{\prime}$ mengandung persamaan kointegrasi jangka panjang

$\mathrm{y}_{\mathrm{t}-1}=$ variabel in-level

$\Gamma_{i x} \quad=$ matriks koefisien regresi

$k-1 \quad=$ ordo VECM dari VAR

$\varepsilon_{\mathrm{t}} \quad=$ error term

Adapun tahap-tahap analisis yang dilakukan adalah sebagai berikut :

\section{Uji Stasionaritas Data}

Tahap pertama yang dilakukan dalam mengolah data time series adalah dengan uji akar unit (unit root test). Uji akar unit ini dilakukan untuk melihat apakah data yang diamati stasioner atau tidak. Data yang stasioner cenderung mendekati nilai rata-rata dan berfluktuasi di sekitar nilai rata-ratanya. Data yang tidak stasioner dapat menghasilkan regresi yang lacung (spurious regression), yaitu regresi yang menggambarkan hubungan dua variabel atau lebih yang terlihat signifikan secara statistik padahal kenyatannya tidak.

Uji stasionaritas data dalam penelitian ini menggunakan Augmented DickeyFuller (ADF). Dalam tes Augmented Dickey-Fuller (ADF), apabila nilai mutlak tADF lebih besar dari nilai mutlak MacKinnon Critical Values-nya maka data telah stasioner pada taraf nyata yang telah ditentukan. Selain itu dapat juga dilihat dari nilai probabilitasnya. Jika data stasioner maka VAR dapat digunakan akan tetapi 
jika tidak stasioner maka ada dua pilihan yaitu menggunakan VAR dalam bentuk first diference atau VECM. Keberadaan variabel yang tidak stasioner meningkatkan kemungkinan adanya hubungan kointegrasi antar variabel.

\section{Uji Lag Optimal}

Lag dalam sebuah sistem VAR merupakan hal yang penting. Di samping berguna untuk menunjukkan berapa lama reaksi suatu variabel terhadap variabel lainnya, penentuan lag optimal juga berguna untuk menghilangkan masalah autokorelasi dalam sebuah sistem VAR (Firdaus 2011).

Pengujian panjang lagyang optimal dapat diidentifikasi dengan menggunakan Akaike Information Criterion (AIC), Schwarz Information Criterion (SIC), HannanQuinn Criterion (HQ), dan sebagainya. Lag yang dipilih adalah model dengan nilai AIC dan SIC terkecil dan nilai HQ terbesar.

\section{Uji Stabilitas VAR}

Uji stabilitas VAR dilakukan dengan menghitung akar-akar dari fungsi polinomial atau dikenal dengan roots of characteristic polinomial. Jika semua akar dari fungsi polinomial tersebut berada di dalam unit circle maka model VAR tersebut dianggap stabil sehingga Impuls Response Function (IRF) dan Forecast Error Variance Decomposition (FEVD) yang dihasilkan dianggap valid (Firdaus 2011).

\section{Uji Kointegrasi}

Uji kointegrasi bertujuan untuk menentukan apakah variabel-variabel yang tidak stasioner terkointegrasi atau tidak. Konsep kointegrasi dikemukakan oleh Engle dan Granger (1987) sebagai kombinasi linear dari dua atau lebih variabel yang tidak stasioner akan menghasilkan variabel yang stasioner. Kombinasi linear ini dikenal dengan istilah persamaan kointegrasi dan dapat diinterpretasikan sebagai hubungan keseimbangan jangka panjang di antara variabel (Firdaus 2011).

Pengujian kointegrasi sendiri dapat dilakukan dengan uji kointegrasi EngleGranger, uji kointegrasi Johansen, dan uji kointegrasi Durbin-Watson. Salah satu uji kointegrasi yang dilakukan dalam penelitian ini adalah uji kointegrasi Johansen. Jika nilai trace statistic lebih besar dari nilai critical value, persamaan tersebut terkointegrasi, dengan $\mathrm{H}_{0}$ sama dengan non-kointegrasi dan $\mathrm{H}_{1}$ sama dengan kointegrasi. Dalam konteks ini, ketika nilai trace statistic lebih besar dari nilai critical value, maka tolak $\mathrm{H}_{0}$ dan terima $\mathrm{H}_{1}$ yang artinya persamaan tersebut terkointegrasi.

\section{Uji Kausalitas Granger}

Uji kausalitas granger dilakukan untuk melihat hubungan kausalitas di antara variabel-variabel yang ada dalam model. Uji ini untuk mengetahui apakah suatu variabel bebas (independent variable) meningkatkan kinerja forecasting dari variabel tidak bebas (dependent variable) (Firdaus 2011). 


\section{Impulse Response Function (IRF)}

Impulse Response Function (IRF) adalah suatu metode yang digunakan untuk menentukan respons suatu variabel endogen terhadap suatu shock tertentu. Hal ini dikarenakan shock variabel, misalnya variabel ke-i, tidak hanya berpengaruh terhadap variabel ke- $i$ itu saja tetapi ditransmisikan kepada semua variabel endogen lainnya melalui struktur dinamis atau struktur lag dalam VAR.

Dengan kata lain, IRF mengukur pengaruh suatu shock pada suatu waktu kepada inovasi variabel endogen pada saat tersebut dan di masa yang akan datang. IRF bertujuan untuk mengisolasi suatu guncangan agar lebih spesifik, yang artinya suatu variabel dapat dipengaruhi oleh shock atau guncangan tertentu. Apabila suatu variabel tidak dapat dipengaruhi oleh shock, maka shock spesifik tersebut tidak dapat diketahui melainkan shock secara umum (Firdaus 2011).

\section{Forecast Error Variance Decomposition (FEVD)}

Analisis FEVD dalam model VAR bertujuan untuk memprediksi kontribusi prosentase varian setiap peubah karena adanya perubahan peubah tertentu dalam sistem VAR. Pada analisis IRF sebelumnya digunakan untuk melihat dampak guncangan dari satu peubah terhadap peubah lainnya, dalam analisis FEVD digunakan untuk menggambarkan relatif pentingnya setiap peubah dalam sistem VAR karena adanya shock (Juanda dan Junaidi 2012).

\section{PEMBAHASAN}

Uji stasionaritas data merupakan tahap yang penting dalam menganalisis data time series. Hasil pengujian akar unit pada level dapat dilihat pada Tabel 3.

Tabel 3 Hasil Pengujian Akar Unit Pada Level

\begin{tabular}{llrrrl}
\hline \multirow{2}{*}{ Variabel } & \multirow{2}{*}{ Nilai ADF } & \multicolumn{3}{c}{ Nilai Kritis Mackinnon } & \multirow{2}{*}{ Keterangan } \\
\cline { 2 - 5 } & & $1 \%$ & $5 \%$ & $10 \%$ & \\
\hline LNJII & -1.643 & -3.530 & -2.905 & -2.590 & Tidak Stasioner \\
LNIPI & -5.046 & -4.099 & -3.477 & -3.166 & Stasioner \\
LNCPI & -2.137 & -4.099 & -3.477 & -3.166 & Tidak Stasioner \\
LNM2 & -3.789 & -4.097 & -3.476 & -3.166 & Stasioner \\
LNER & -2.115 & -3.530 & -2.905 & -2.590 & Tidak Stasioner \\
BIRATE & -3.041 & -4.099 & -3.477 & -3.166 & Tidak Stasioner \\
SBIS & -2.345 & -3.529 & -2.904 & -2.590 & Tidak Stasioner \\
LNDJIEU & -1.596 & -3.529 & -2.904 & -2.590 & Tidak Stasioner
\end{tabular}


Irfan Syauqi Beik: Pengaruh Indeks Harga Saham Syariah Internasional

\begin{tabular}{llllll} 
LNDJIMY & -1.368 & -3.530 & -2.905 & -2.590 & Tidak Stasioner \\
LNIMUS & -1.014 & -3.529 & -2.904 & -2.590 & Tidak Stasioner \\
LNDJIJP & -2.102 & -3.530 & -2.905 & -2.590 & Tidak Stasioner \\
\hline
\end{tabular}

Hasil uji stasionaritas data pada level menunjukkan bahwa semua variabel tidak stasioner kecuali (IPI) dan (M2) yang stasioner pada taraf nyata 5\%. Hal ini dikarenakan nilai mutlak t-ADF lebih kecil dari nilai mutlak MacKinnon Critical Values-nya pada taraf 5\%. Penelitian dengan data yang tidak stasioner dapat menghasilkan regresi palsu (spurious regression). Karena itu, uji stasionaritas dilanjutkan pada tingkat first difference.

Tabel 4 Hasil Pengujian Akar Unit Pada First Difference

\begin{tabular}{llrrrl}
\hline Variabel & Nilai ADF & \multicolumn{3}{c}{ Nilai Kritis Mackinnon } & Keterangan \\
\cline { 3 - 5 } & & $1 \%$ & $5 \%$ & $10 \%$ & \\
\hline DLNJII & -6.067 & -3.530 & -2.905 & -2.590 & Stasioner \\
DLNIPI & -6.852 & -3.533 & -2.906 & -2.591 & Stasioner \\
DLNCPI & -5.393 & -4.101 & -3.478 & -3.167 & Stasioner \\
DLNM2 & -8.126 & -3.532 & -2.906 & -2.590 & Stasioner \\
DLNER & -6.203 & -3.530 & -3.530 & -2.590 & Stasioner \\
DBIRATE & -3.603 & -3.530 & -2.905 & -2.590 & Stasioner \\
DSBIS & -13.004 & -3.530 & -2.905 & -2.590 & Stasioner \\
DLNDJIEU & -6.583 & -3.530 & -2.905 & -2.590 & Stasioner \\
DLNDJIMY & -6.422 & -3.530 & -2.905 & -2.590 & Stasioner \\
DLNIMUS & -6.633 & -3.530 & -2.905 & -2.590 & Stasioner \\
DLNDJIJP & -6.274 & -3.530 & -2.905 & -2.590 & Stasioner \\
\hline
\end{tabular}

Hasil uji stasionaritas data pada Tabel 4 menunjukkan bahwa semua data yang digunakan dalam penelitian telah stasioner pada tingkat first difference. Hal ini dikarenakan nilai mutlak t-ADF lebih besar dari nilai mutlak MacKinnon Critical Values-nya pada taraf nyata $5 \%$.

Dalam model VAR penentuan lag optimal sangat berguna untuk menghilangkan autokorelasi. Hasil pengujian lag optimal dapat dilihat pada Tabel 5. Berdasarkan perhitungan nilai Akaike Information Criterion (AIC), lag optimal berada pada lag tiga. 
Tabel 5. Pengujian Lag Optimal

\begin{tabular}{cc}
\hline Lag & AIC \\
\hline 0 & -25.32866 \\
1 & -41.28332 \\
2 & -42.08743 \\
3 & $-42.70146^{*}$ \\
\hline
\end{tabular}

Catatan: Tanda * menunujukkan angka terkecil

Model VAR dianggap stabil apabila seluruh roots-nya memiliki modulus lebih kecil dari satu dan berada di dalam unit circle. Nilai modulus untuk model penelitian Jakarta Islamic Index ini berkisar antara 0.217998- 0.996523. Berdasarkan hasil tersebut maka dapat disimpulkan bahwa model VAR stabil.

Semua variabel telah stasioner pada tingkat first difference, sehingga uji kointegrasi melalui Johansen Cointegration Test dapat dilakukan. Hasil dari uji kointegrasi ini adalah sebagaimana yang terangkum dalam Tabel 6 berikut ini.

Tabel 6 Hasil Pengujian Kointegrasi

\begin{tabular}{llcc}
\hline $\begin{array}{c}\text { Hypothesized No.of } \\
\text { CE(s) }\end{array}$ & Eigenvalue & Trace Statistic & 5 Persent Critical Value \\
\hline None & & & \\
At most $1^{*}$ & 0.757689 & 430.9355 & 263.2603 \\
At most 2* & 0.660536 & 335.9607 & 219.4016 \\
At most 3* & 0.612711 & 263.5748 & 179.5098 \\
At most 4* & 0.581392 & 200.0198 & 143.6691 \\
At most 5* & 0.494200 & 141.6748 & 111.7805 \\
At most 6* & 0.365467 & 96.00665 & 83.93712 \\
At most 7* & 0.305600 & 65.53065 & 60.06141 \\
At most 8 & 0.260460 & 41.09533 & 40.17493 \\
At most 9 & 0.184656 & 20.87958 & 24.27596 \\
At most 10 & 0.090104 & 7.201838 & 12.32090 \\
\hline
\end{tabular}

Catatan: Tanda * menunjukkan signifikan pada taraf 5\%

Hasil pengujian pada Tabel 6 menunjukkan bahwa dengan menggunakan taraf nyata $5 \%$, terdapat delapan persamaan yang terkointegrasi. Hal tersebut dapat dilihat saat nilai Trace statistic > Critical Value. Informasi mengenai terdapatnya persamaan yang terkointegrasi ini akan dilanjutkan dengan menggunakan model 
Vector Error Correction Model (VECM).

Hasil uji kausalitas Granger adalah sebagaimana terangkum pada Tabel 7. Hasil uji ini menunjukkan bahwa tidak terdapat hubungan hubungan dua arah diantara variabel. Dapat diketahui bahwa secara Granger CPI memengaruhi BI Rate, BI Rate memengaruhi DJIMY, BI Rate memengaruhi JII, BI Rate memengaruhi SBIS, IPI memengaruhi CPI, CPI memengaruhi JII, dan M2 memengaruhi CPI. Sementara itu, DJIEU memengaruhi ER, DJIJP memengaruhi ER, DJIMY memengaruhi ER, DJIMY memengaruhi M2, IMUS memengaruhi ER, dan JII memengaruhi ER.

\section{Tabel 7 Hasil Kausalitas Granger}

\begin{tabular}{lc}
\hline \multicolumn{1}{c}{ HIPOTESIS } & PROBABILITY \\
\hline DLNCPI does not Granger Cause DBIRATE & 0.0089 \\
DBIRATE does not Granger Cause DLNDJIMY & 0.0364 \\
DBIRATE does not Granger Cause DLNJII & 0.002 \\
DBIRATE does not Granger Cause DSBIS & 0.0001 \\
DLNIPI does not Granger Cause DLNCPI & 0.0113 \\
DLNCPI does not Granger Cause DLNJII & 0.0267 \\
DLNM2 does not Granger Cause DLNCPI & 0.0004 \\
DLNDJIEU does not Granger Cause DLNER & $4 . E-06$ \\
DLNDJIJP does not Granger Cause DLNER & $4 . E-05$ \\
DLNDJIMY does not Granger Cause DLNER & $7 . E-05$ \\
DLNDJIMY does not Granger Cause DLNM2 & 0.0279 \\
DLNIMUS does not Granger Cause DLNER & $3 . E-05$ \\
\hline DLNJII does not Granger Cause DLNER & $8 . E-09$ \\
\hline
\end{tabular}

Estimasi VECM dilakukan untuk melihat adanya hubungan jangka pendek dan jangka panjang. Pada jangka pendek terdapat koreksi kesalahan sebesar 0.74657, hal ini mengindikasikan untuk menuju keseimbangan jangka panjang diperlukan koreksi sebesar 0.74657 persen

Tabel 8 Hasil VECM

\begin{tabular}{lcc}
\hline \multicolumn{3}{c}{ JANGKA PANJANG } \\
\hline VARIABEL & KOEFISIEN & T-STATISTIC \\
\hline BIRATE $(-1)$ & -0.01154 & -1.20634 \\
LNCPI(-1) & 0.45827 & 1.12589 \\
LNDJIEU $(-1)$ & 0.63652 & 5.56779
\end{tabular}




\begin{tabular}{lcc} 
LNDJIJP(-1) & -0.53719 & -5.56169 \\
LNDJIMY(-1) & 1.04431 & 28.32000 \\
LNER(-1) & -0.18877 & -1.65012 \\
LNIMUS(-1) & -0.82999 & -6.08749 \\
LNIPI(-1) & 1.64438 & 10.52420 \\
LNM2(-1) & -0.42506 & -2.43573 \\
SBIS(-1) & -0.03183 & -5.25776 \\
C & -0.64856 & - \\
\hline
\end{tabular}

$$
\text { C }
$$

JANGKA PENDEK

\begin{tabular}{lcc}
\hline \multicolumn{1}{c}{ VARIABEL } & KOEFISIEN & T-STATISTIC \\
\hline CointEq1 & -0.74657 & -1.97657 \\
D(LNJII(-1)) & 0.18710 & 0.56180 \\
D(LNJII (-2)) & 0.05910 & 0.17288 \\
D(LNJII (-3)) & 0.42413 & 1.33743 \\
D(BIRATE(-1)) & 0.11791 & 0.89603 \\
D(BIRATE(-2)) & -0.08831 & -0.67981 \\
D(BIRATE(-3)) & -0.08339 & -0.88808 \\
D(LNCPI(-1)) & -4.78917 & -1.23061 \\
D(LNCPI (-2)) & -0.97027 & -0.19623 \\
D(LNCPI (-3)) & -6.44818 & -1.78322 \\
D(LNDJIEU(-1)) & -0.55385 & -0.83121 \\
D(LNDJIEU(-2)) & 0.18203 & 0.26207 \\
D(LNDJIEU(-3)) & -0.70540 & -1.12677 \\
D(LNDJIJP(-1)) & 0.45205 & 0.95687 \\
D(LNDJJP(-2)) & -0.35314 & -0.73910 \\
D(LNDJIJP(-3)) & 1.11652 & $2.12999^{*}$ \\
D(LNDJIMY(-1)) & -0.21360 & -0.47448 \\
D(LNDJIMY(-2)) & 0.21777 & 0.56826 \\
D(LNDJIMY(-3)) & -0.11112 & -0.27233 \\
D(LNER(-1)) & 0.75505 & 1.07020 \\
D(LNER(-2) $)$ & 0.55772 & 0.81596 \\
D(LNER(-3)) & 0.05373 & 0.11670 \\
D(LNIMUS(-1)) & 1.13044 & 1.32693 \\
D(LNIMUS(-2)) & 0.07766 & 0.10314 \\
D(LNIMUS(-3)) & -0.12892 & -0.21590 \\
& &
\end{tabular}




\begin{tabular}{lll} 
D(LNIPI(-1)) & -1.47684 & -1.95938 \\
D(LNIPI(-2)) & -1.36728 & $-2.02174^{*}$ \\
D(LNIPI(-3)) & -0.81425 & -1.64192 \\
D(LNM2(-1)) & 0.43578 & 0.54009 \\
D(LNM2(-2)) & 0.24299 & 0.30263 \\
D(LNM2(-3)) & 0.41502 & 0.46026 \\
D(SBIS(-1)) & 0.00940 & 0.42952 \\
D(SBIS(-2)) & 0.03116 & 1.18580 \\
D(SBIS(-3)) & 0.02621 & 1.19119 \\
C & 0.05260 & 1.60846 \\
\hline
\end{tabular}

Catatan: Tanda * menunjukkan signifikan pada taraf 5\%

Hasil estimasi VECM pada jangka pendek menunjukkan bahwa DJIJP pada lag ketiga memengaruhi JII secara signifikan yaitu sebesar 1.11652.Artinya, apabila terjadi kenaikan DJIJP sebesar satu persen maka JII naik sebesar 1.11652 persen. IPI pada lag kedua memengaruhi JII secara signifikan yaitu sebesar -1.36728. Artinya, apabila terjadi kenaikan IPI sebesar satu persen maka JII menurun sebesar 1.36728 persen.

Hasil estimasi VECM pada jangka panjang menunjukkan bahwa BI Rate tidak mempengaruhi JII secara signifikan, meski tanda hubungan keduanya adalah negatif. Hasil ini berbeda dengan temuan Hussin et al. (2012) yang menyatakan bahwa suku bunga berpengaruh negatif signifikan terhadap harga saham. Terjadinya perbedaan ini dikarenakan prinsip dasar JII yang berlandaskan syariah, dimana suku bunga adalah instrumen yang tidak sesuai syariah. Demikian pula dengan hubungan antara inflasi dengan JII, dimana CPI tidak memengaruhi JII secara signifikan. Artinya, kenaikan inflasi tidak otomatis akan menaikkan harga saham yang terdaftar di JII.

Variabel berikutnya adalah nilai tukar rupiah terhadap dolar AS (ER). Hasil riset menunjukkan bahwa ER tidak berpengaruh signifikan terhadap JII, meskipun tanda hubungan keduanya adalah negatif. Berbeda dengan penelitian Ibrahim dan Yusoff (2001), Menike (2006), Yusof dan Majid (2009), Syukma (2011), Kuwomu dan Victor (2011), Hussin et al. (2012), Bekhet dan Mugableh (2012), dan Majid et al. (2012) yang menunjukkan bahwa ER dan harga saham memiliki hubungan signifikan dan negatif. Tidak signifikannya pengaruh ER terhadap JII mengindikasikan bahwa jumlah investor asing yang menginvestasikan dananya di JII tidak terlalu banyak. 
Variabel makro lainnya, yaitu IPI terbukti berpengaruh signifikan dan positif terhadap JII. Hasil studi menunjukkan bahwa peningkatan IPI sebesar satu persen akan meningkatkan JII sebesar 1.64438 persen. Peningkatan IPI akan memengaruhi harga saham melalui dampaknya terhadap keuntungan perusahaan. Ketika nilai IPI naik, maka kondisi sektor riil mengalami pertumbuhan positif. Ini berarti kinerja perusahaan mengalami peningkatan. Baiknya kinerja perusahaan, terutama perusahaan yang listed di bursa, akan memicu kenaikan harga saham perusahaan tersebut. Ini membuktikan adanya korelasi yang kuat antara kinerja sektor riil dengan indeks harga di pasar saham syariah.

Jumlah uang yang beredar (M2) terbukti berpengaruh secara signifikan dan negatif terhadap JII. Peningkatan M2 sebesar satu persen diketahui akan menurunkanJII sebesar 0.42506 persen. Selain M2,SBIS juga diketahui memengaruhi JII secara signifikan dan negatif. Kenaikan SBIS sebesar satu persen akan menyebabkan penurunan JII sebesar 0.03183 persen. Hal ini sangat menarik karena SBIS dan JII adalah dua instrumen yang berada di pasar yang berbeda. Hasil ini mengindikasikan bahwa SBIS di mata investor merupakan instrumen substitusi bagi JII, sehingga kenaikan di salah satu instrumen akan menyebabkan penurunan pada instrumen yang lain.

Selanjutnya, dalam konteks hubungan antar pasar saham syariah internasional dengan JII, hasil penelitian menunjukkan bahwa pasar saham syariah Eropa memengaruhi JII secara positif dan signifikan. Dari Tabel 8 di atas dapat diketahui bahwa kenaikan DJIEU sebesar satu persen akan meningkatkan JII sebesar 0.63652 persen. Demikian pula halnya dengan pasar saham syariah Malaysia yang memengaruhi JII secara positif dan signifikan. Kenaikan DJIMY sebesar satu persen akan meningkatkan JII sebesar 1.04431 persen.

Berbeda dengan kedua pasar di atas, pasar saham syariah Jepang dan Amerika Serikat justru berkorelasi negatif dan signifikan dengan JII. Peningkatan indeks DJIJP sebesar satu persen akan menurunkan JII sebesar 0.53719 persen. Sedangkan kenaikan IMUS sebesar satu persen akan menyebabkan penurunan JII sebesar 0.82999 persen. Hasil riset ini mengindikasikan bahwa para investor lebih memilih untuk menginvestasikan dananya di pasar saham syariah Jepang dan Amerika Serikat dibandingkan dengan JII, jika pergerakan indeks di kedua negara tersebut menunjukkan tren yang positif. Ini menunjukkan bahwa pasar saham syariah kedua negara tersebut adalah kompetitor bagi pasar saham syariah domestik. Disinilah kemampuan Indonesia diuji, bagaimana pasar saham syariah negeri ini mampu menarik sebanyak-banyaknya dana investasi bagi kemajuan dan stabilitas perekonomian nasional.

Dari Gambar 2 di bawah ini, yang menunjukkan hasil Impulse Response Function 
(IRF), dapat diketahui bahwa ketika terjadi guncangan pada BI Rate, maka JII akan merespon secara negatif pada bulan kedua, dan kemudian menurun secara drastis hingga bulan kesembilan. Setelah itu mengalami fluktuasi hingga bulan ke-35, dan baru kemudian mencapai kestabilan.

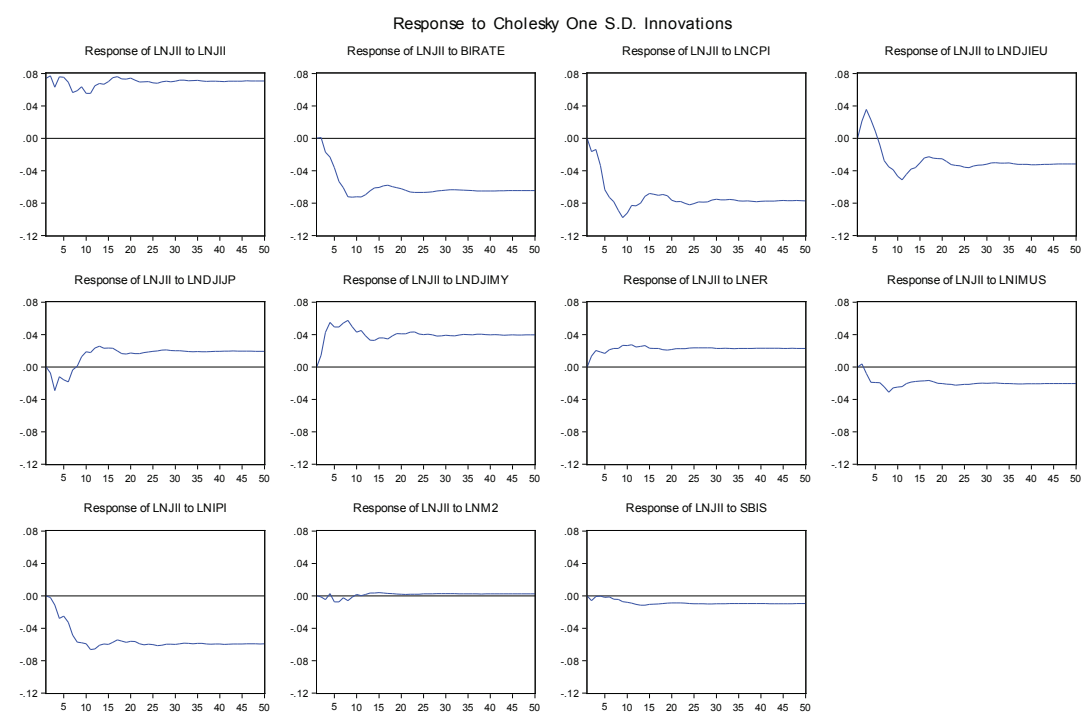

Gambar 2. Hasil Impulse Response Function

Ketika terjadi guncangan terhadap CPI, JII akan merespon negatif mulai bulan kedua hingga bulan kesembilan, kemudian berfluktuasi dan kembali stabil mulai bulan ke-35 hingga akhir periode pengamatan. Demikian pula halnya dengan ER. Ketika terjadi guncangan pada nilai tukar rupiah terhadap dolar AS, maka JII akan merespon secara positif pada bulan kesebelas, kemudian setelah itu kondisi relatif stabil, meski masih terdapat fluktuasi yang relatif sangat kecil.

Variabel makroekonomi selanjutnya adalah IPI. JII merespon secara negatif terhadap gejolak yang terjadi pada IPI atau sektor riil hingga bulan kesebelas. Kemudian naik dan mengalami fluktuasi hingga bulan ke-30. Setelah itu JII kembali stabil di respon negatif. Adapun terhadap guncangan yang menimpa jumlah uang yang beredar (M2), JII relatif tidak terlalu merespon secara drastis. Dengan kata lain, tingkat fluktuasinya sangat kecil. JII merespon negatif pada bulan kedua, kemudian direspon positif pada bulan keempat. Pada bulan kelima, JII kembali meresponnya secara negatif. Respon positif muncul pada bulan ke-10 dan setelah itu kembali stabil hingga akhir periode pengamatan. Sedangkan guncangan terhadap SBIS akan direspon secara negatif oleh JII pada bulan kedua. Setelah itu kondisi kembali stabil 
direspon negatif hingga akhir periode pengamatan.

Dalam konteks keterkaitan dengan pasar saham syariah Eropa, JII akan merespon secara positif guncangan terhadap DJIEU pada bulan kedua hingga bulan kelima. Namun demikian, respon JII ini menjadi negatif pada bulan keenam, dan selanjutnya stabil di respon negatif hingga akhir periode pengamatan. Ketika pasar saham syariah Jepang mengalami shock, JII akan merespon secara negatif terhadap DJIJP pada bulan kedua, kemudian direspon positif pada bulan kedelapan, setelah itu stabil di respon positif.

Terhadap pasar Malaysia, Gambar 2 juga menunjukkan bahwa ketika terjadi gejolak pada pasar saham syariah Malaysia, maka JII akan merespon positif DJIMY pada bulan kedua. Setelah itu mengalami kestabilan di respon positif, meski sempat mengalami fluktuasi. Sedangkan terkait pasar saham syariah Amerika Serikat, maka guncangan pada IMUS pada mulanya akan direspon secara positif di bulan kedua, kemudian respon negatif di bulan ketiga hingga bulan kedelapan. Setelah itu IMUS pun stabil di respon negatif, meski sempat terjadi fluktuasi.

Dari penjelasan di atas, dapat disimpulkan bahwa JII paling cepat mencapai kestabilan ketika merespon guncangan yang terjadi terhadap jumlah uang yang beredar, dibandingkan dengan variabel-variabel lainnya.

Dari hasil FEVD terhadap JII terlihat bahwa pada bulan pertama, kontribusi terhadap keragaman (variability) indeks JII 100 persen berasal dari JII itu sendiri. Prosentase ini kemudian mengalami penurunan secara bertahap hingga akhir periode pengamatan. Kemudian pada bulan ke-11 CPI adalah variabel yang paling besar kontribusinya terhadap keragaman JII, yaitu sebesar 25.99 persen.Kondisi ini bertahan hingga bulan ke-50 dimana CPI ini tetap menjadi variabel yang paling besar kontribusinya terhadap keragaman JII, yaitu sebesar 26.11 persen.

Variabel-variabel lain di luar CPI juga berkontribusi terhadap keragaman JII dengan nilai yang berbeda-beda menunjukkan bahwa di akhir periode pengamatan, atau pada bulan ke-50, BI Rate memberikan kontribusi sebesar 17.81 persen, ER sebesar 2.39 persen,IPI sebesar 14.63 persen, M2 sebesar 0.04 persen dan SBIS 0.38 persen. Hal menarik dari hasil ini adalah masih besarnya kontribusi suku bunga Bank Indonesia terhadap keragaman JII. Ini menunjukkan perilaku investor yang tidak sepenuhnya loyalis syariah, sehingga mereka masih membandingkan keuntungan berinvestasi di pasar modal syariah dengan di pasar uang konvensional. Sementara itu, kontribusi pasar saham syariah internasional terhadap keragaman JII juga bervariasi. DJIEU memberikan kontribusi sebesar 4.73 persen, DJIJP sebesar 1.64 persen, DJIMY sebesar 7.67 persen, dan IMUS sebesar 1.94 persen. Hasil ini mengindikasikan bahwa pasar saham syariah Malaysia, sebagai negara tetangga 
terdekat Indonesia, memiliki kontribusi yang paling besar terhadap keragaman JII dibandingkan dengan ketiga negara lainnya.

\section{SIMPULAN}

Berdasarkan hasil penelitian maka diperoleh beberapa kesimpulan. Pertama, hasil analisis VECM menunjukkan bahwa pada jangka pendek, hanya DJIJP dan IPI yang memengaruhi JII secara signifikan. Sedangkan pada jangka panjang, DJIEU, DJIMY dan IPI memiliki hubungan positif secara signifikan terhadap JII. Adapun DJIJP, IMUS, M2 dan SBIS memiliki hubungan yang negatif signifikan terhadap JII. Sementara itu, CPI, BI Rate dan ER tidak memiliki hubungan yang signifikan dengan JII.

Kedua, hasil IRF menunjukkan bahwaJII mengalamifluktuasi dalam merespon guncangan atau shock yang terjadi terhadap seluruh variabel makroekonomi dan pasar saham syariah internasional yang diamati, sebelum kemudian mencapai kestabilan. Waktu yang diperlukan untuk mencapai kondisi stabil ini berbeda-beda di antara variabel tersebut. JII paling cepat mencapai kestabilan ketika merespon guncangan pada jumlah uang yang beredar. Ketiga, hasil analisis FEVD menunjukkan bahwa setiap variabel memiliki kontribusi yang berbeda-beda terhadap keragaman JII. Di akhir periode pengamatan, CPI adalah variabel yang memiliki kontribusi paling besar, sementara M2 adalah variabel yang memiliki kontribusi yang paling kecil.

Dari hasil penelitian di atas, ada empat rekomendasi kebijakan yang dapat diambil. Pertama, dari hasil VECM diketahui bahwa instrumen moneter syariah ternyata memiliki hubungan jangka panjang dengan pasar saham syariah, dimana SBIS berhubungan negatif dan signifikan dengan JII. Dengan fakta seperti ini, maka koordinasi antara otoritas moneter dengan otoritas jasa keuangan yang mensupervisi pasar saham syariah, menjadi sangat krusial. Kedua otoritas ini perlu melakukan edukasi yang tepat dan efektif kepada para investor bahwa instrumen SBIS dan JII ini bukan instrumen yang saling mensubstitusi sehingga berpotensi untuk saling melemahkan. Sehingga, diharapkanpara investor akan menjadikan SBIS dan JII ini sebagai alat investasi yang bersifat komplementer, atau saling melengkapi dan memperkuat satu sama lain.

Kedua, perlunya penguatan sektor riil perekonomian. Hasil VECM dan FEVD menjadi bukti bahwa variabel IPI memiliki posisi yang sangat strategis karena IPI memiliki hubungan jangka panjang yang signifikan dengan JII, dan berkontribusi terhadap keragaman JII sebesar 14.63 persen. Oleh karena itu, pemerintah harus dapat menjaga momentum pertumbuhan sektor riil ini, karena akan sangat memengaruhi kinerja pasar saham syariah nasional. 
Ketiga, perlu dirumuskan formulasi yang efektif untuk meminimalisir pengaruh suku bunga terhadap pasar modal syariah, karena hasil riset menunjukkan bahwa BI Rate masih memiliki kontribusi terhadap keragaman JII sebesar 17.81 persen, meski tidak memiliki hubungan signifikan dengan JII pada jangka panjang. Formulasi ini sangat penting sehingga baik pasar saham syariah maupun pasar keuangan syariah secara umum, bisa terbebas sepenuhnya dari pengaruh suku bunga. Keempat, perlu dibangun early warning system atau sistem peringatan dini untuk mendeteksi dan mengatasi dampak dari gejolak yang terjadi di pasar saham syariah negara lain. Tujuannya agar daya tahan pasar saham syariah Indonesia bisa semakin kuat sehingga dapat ikut terlibat menjaga stabilitas perekonomian nasional.

\section{PUSTAKA ACUAN}

Abidin, Z. 2008. Analisis Keterkaitan Antara Indeks Saham Syariah di Beberapa Negara dan Indeks Saham Jakarta Islamic Index (JII) di Indonesia [skripsi]. Bogor: Institut Pertanian Bogor.

Albaity, MS. 2011. Impact of The Monetary Policy Instruments on Islamic Stock Market Index Return. Discussion paper, no. 2011-26.

Asmy, M, et al. 2010. Effects of Macroeconomic Variables on Stock Prices in Malaysia: An Approach of Error Correction Model. MPRA Paper. No.20970.

Beik, I.S \& W. Wardhana. 2011. The Relationship between Jakarta Islamic Index and Other Selected Markets: Evidence from Impulse Response Function. Majalah Ekonomi. Vol.XXI No.2.

Bekhet, H.A. \& M.I. Mugableh. 2012. Investigating Equilibrium Relationship between Macroeconomic Variables and Malaysian Stock Market Index through Bounds Tests Approach. International Journal of Economics and Finance. Vol.4 No.10.

Brooks, C. 2002. Introductory Econometrics for Finance. Cambridge: Cambridge University Press.

Darmadji, T \& H.M. Fakhrudin. 2001. Pasar Modal Indonesia Pendekatan Tanya Jawab. Jakarta: Salemba Empat.

Firdaus, M. 2011. Aplikasi Ekonometrika Untuk Data Panel dan Time Series. Bogor: IPB Press.

Heykal M \& N. Huda. 2010. Lembaga Keuangan Islam Tinjauan Teoritis dan Praktis. Jakarta: Kencana Prenada Media Group.

Hosseini, SM, et.al. 2011. The Role of Macroeconomic Variables on Stock Market Index in China and India. International Journal of Economics and Finance. Vol.3 No.6.

Huda, N \& ME Nasution. 2008. Investasi pada Pasar Modal Syariah. Jakarta: 
Kencana Prenada Media Group.

Hussin, M.Y.M, et.al. 2012. Macroeconomic Variable and Malaysian Islamic Stock Market: A time Series Analysis. Journal of Business Studies Quarterly. Vol.3 No.4, pp.1-13.

Ibrahim, M.H. \& W.S.W. Yussoff. 2001. Macroeconomic Variables, Exchange Rate and Stock Price: A Malaysian Perspective. Journal of Economics and Management. Vol.9 No.2, pp. 141-164.

Istiqomah. 2012. Dinamika Interaksi Antara Variabel Moneter dan Pasar Modal Syariah terhadap Pertumbuhan Ekonomi Indonesia [skripsi]. Bogor: Institut Pertanian Bogor.

Juanda B \& Junaidi. 2012. Ekonometrika Deret Waktu Teori dan Aplikasi. Bogor: IPB Press.

Kuwomu, JKM \& ON. Victor. 2011. Macroeconomic Variables and Stock Market Returns: Full Information Maximum Likelihood Estimation. Journal of Finance and Accounting. Vol. 2 No.4.

Lipsey, R.G, et.al. 1992. Pengantar Makroekonomi.. Jakarta: Erlangga.

Maghayereh, A. 2003. Causal Relations among Stock Prices and Macroeconomic Variables in the Small, Open Economy of Jordan. Journal Economics and Adm. Vol.17 No.2, pp. 3-12.

Mankiw, N.G. 2006. Makroekonomi. Jakarta: Erlangga.

Majid, M.S.A \& R.M. Yusof. 2009. Long-run relationship between Islamic stock returns and macroeconomic variables An application of the autoregressive distributed lag model. Humanomics Journal. Vol.25 No.2, pp.127-141.

Maysami, R.C, et.al. 2004. Relationship between Macroeconomic Variables and Stock Market Indices: Cointegration Evidence from Stock Exchange of Singapore's All-S Sector Indices. Jurnal Pengurusan. Vol.24, pp. 47-77.

Menike, L.M.C.S. 2006. The Effect of Macroeconomic Variables on Stock Prices in Emerging Sri Lankan Stock Market. Sabaragamuwa University Journal. Vol.6 No.1, pp 50-67.

Nugraha, G.P. 2007. Analisis Pengaruh Perkembangan Pasar Modal terhadap Pertumbuhan Ekonomi Indonesia [skripsi]. Bogor: Institut Pertanian Bogor.

Rad, A.A. 2011. Macroeonomic Variables and Stock Market: Evidence From Iran. International Journal of Economics and Finance Studies. Vol. 3 No. 1.

Savasa, B \& F. Samiloglub. 2010. The Impact Of Macroeconomic Variables On Stock Returns in Turkey: An ARDL Bounds Testing Approach. Afyon Kocatepe Universitesi. Vol II.

Syukma, N.H. 2011. Faktor-faktor Makroekonomi yang Mempengarubi Return Saham Batubara dalam Kelompok Jakarta Islamic Index [skripsi]. Bogor: 
Institut Pertanian Bogor.

Widoatmodjo, S. 2009. Pasar Modal Indonesia: Pengantar dan Studi Kasus. Bogor: Ghalia Indonesia.

Yusof, R.M, et.al. 2006. Macroeconomic Variables and Stock Returns in the Post 1997 Financial Crisis: An Application of the ARDL Model. Global Conference on Business and Economics, Gutman Conference Center, USA, Oktober 2006.

Yusof, R.M \& Majid, M.S.A. 2007. Stock Market Volatility Transmission in Malaysia:Islamic Versus Conventional Stock Market. Journal Islamic Economics. Vol. 20 No. 2, pp. 17-35. 